\title{
Thermo-chemical conditions of Mesozoic metasomatism at the southwestern Kaapvaal SCLM
}

\author{
Yaakov Weiss ${ }^{1}$, Oded Navon ${ }^{2}$, Steven L. Goldstein ${ }^{1}$ and Jeff W. Harris ${ }^{3}$ \\ ${ }^{1}$ Lamont-Doherty Earth Observatory of Columbia University, New York, United States, \\ yweiss@ldeo.columbia.edu, steveg@ldeo.columbia.edu \\ ${ }^{2}$ The Hebrew University of Jerusalem, Jerusalem, Israel, oded.navon@mail.huji.ac.il \\ ${ }^{4}$ University of Glasgow, Glasgow, United Kingdom, Jeff.Harris@glasgow.ac.uk
}

\section{Introduction}

The SCLM of the southwestern part of the Kaapvaal Craton in South Africa has been studied intensively. Mantle derived xenoliths and xenocrysts from this area document intensive Archean melt extraction, followed by a complex metasomatic history. The timing of metasomatism coincides with Archean subduction events during and after amalgamation of the Craton, and with Proterozoic and early Phanerozoic orogenies. 'Young' metasomatism is attributed to Mesozoic magmatism, by both Karoo flood basalts (175$185 \mathrm{Myr}$ ) and the eruptions of Group II (mainly at $125 \pm 10 \mathrm{Myr}$ ) and Group I (at 85 $\pm 5 \mathrm{Myr}$ ) kimberlites. Along with chemical modifications, mantle metasomatism is responsible for both thermal perturbation and changes in the oxygen fugacity $\left(f \mathrm{O}_{2}\right)$ of the SCLM; where mantle xenoliths and xenocrysts are likely to record mainly the changes resulting from the last metasomatic event. Temperature variations recorded by xenoliths are commonly interpreted as the result of Cretaceous metasomatism, occuring between the Group II and Group I kimberlite episodes, while metasomatic $f \mathrm{O}_{2}$ increases from core-to-rim in some xenolithic garnets are estimated to take place within $<1 \mathrm{Ma}$ of kimberlite eruptions.

Here, we focus on the recent metasomatic events that took place at the southwestern Kaapvaal SCLM. However rather than investigating the chemical changes of lithospheric rocks and inferring the metasomatic agent involved, we look directly at the fluids and melts responsible for alteration, by analyzing the composition of $\mu \mathrm{m}$ size inclusions in boart diamonds. We report nitrogen agregation and the major- and trace-element data for a suite of eight microinclusion-bearing diamonds DeBeers-Pool kimberlites (i.e. four kimberlites around Kimberley, South Africa). Combining our results with data on mineral inclusions in monocrystalline diamonds and garnet-bearing peridotite xenoliths from DeBeers-Pool and related kimberlites in the southwestern Kaapvaal region, we discuss the source and evolution of the metasomatic agent, the possible timing of alteration and young diamond growth, and the impact of Mesozoic metasomatism and volcanism on the thermal and redox state of the lithosphere.

\section{Results}

Seven of the diamonds are rich in saline high density fluids (HDFs, Fig. 1a), carry peridotitic mineral microinclusions and are characterized by a nitrogen IaA Type IR spectrum. Their trace-element patterns show high alkalis ( $\mathrm{K}, \mathrm{Rb}$ and $\mathrm{Cs}$ ), Ba and LREEs compared to Th, $\mathrm{U}, \mathrm{Nb}$ and $\mathrm{Ta}$ and are characterized by negative anomalies of Ti, $\mathrm{Zr}$, Hf and Y relative to REEs of similar compatibility. Major and trace element compositions show intra- and inter-diamond relationships. The molar $(\mathrm{K}+\mathrm{Na}) / \mathrm{Cl}$ ratio varies between $1.01 \pm 0.09(1 \sigma)$ and 1.55 \pm 0.31 , and correlates with a general increase of $\mathrm{MgO}, \mathrm{SiO}_{2}$ and $\mathrm{Na}_{2} \mathrm{O}$ (and $\mathrm{CaO}$, $\mathrm{Al}_{2} \mathrm{O}_{3}$ and $\mathrm{P}_{2} \mathrm{O}_{3}$ to some extent). Trace-element patterns and ratios vary with $\mathrm{Cl}$ and $\mathrm{MgO}$ (and carbonate). In general, with decreasing $\mathrm{Cl}$ and increasing $\mathrm{MgO}$, the $\mathrm{La} / \mathrm{Pr}$ ratio increases and $\mathrm{Eu} / \mathrm{Sm}$ and $\mathrm{Ba} / \mathrm{Nb}$ ratios decrease; $\mathrm{Sr} / \mathrm{Rb}, \mathrm{Th} / \mathrm{Rb}$ and $\mathrm{Zr} / \mathrm{Hf}$ ratios increase and the $\mathrm{Eu} / \mathrm{Ti}$ ratio decrease, due to higher $\mathrm{Sr}, \mathrm{Th}, \mathrm{Zr}$ and Ti concentrations. The change, from saline towards somewhat more saline-carbonatitic compositions appears between diamonds in which no mineral microinclusions were found and diamonds containing both HDFs and mineral microinclusions, and likely represent increasing fluid-rock interaction. Another diamond that trapped silicic HDFs exhibits an IaAB-Type spectrum with $25 \%$ of the nitrogen in B-centers and 
associated nitrogen platelets. No mineral microinclusions were found in this diamond. Comparison of the trace-element pattern of this diamond to those of saline HDFs reveals similar levels of Th, $U$ and Ba, which are all elevated compared to alkalis, a smaller negative $\mathrm{Ti}$ anomaly, and positive $\mathrm{Zr}$ and $\mathrm{Hf}$ anomalies (Fig. $1 b)$.

Mixing between minerals and saline HDFs exist in some microinclusions in the different diamonds. We used linear regressions, which are best manifested on oxide (e.g. $\mathrm{MgO}, \mathrm{SiO}_{2}$ ) vs. Cl wt.\% variation diagrams, to determine the mixing lines and the compositions of $\mathrm{Ol}, \mathrm{Opx}, \mathrm{Cpx}$, Grt and $\mathrm{Mgs}$ at $\mathrm{Cl}=0 \mathrm{wt} . \%$. We then calculated the temperature and pressure conditions for saline metasomatism and diamond formation, using different thermometers and barometers and the composition of HDF-free Ol, Grt, Cpx and Opx. The variation in temperature is $\sim 200^{\circ} \mathrm{C}$ at a given pressure between $4-8 \mathrm{GPa}$ (Fig. 2a). For example, at $5 \mathrm{GPa}$ the possible temperature range is between $875-1080^{\circ} \mathrm{C}$. Oxygen fugacities for the saline metasomatism were calculated using the mole fraction of $\mathrm{CO}_{2}$ in the HDFs and the range of temperature and pressure for saline metasomatism, using the calibration of Stagno and Frost (2010). The calculated range of $\log \mathrm{SO}_{2}$ (relative to the FMQ buffer) for saline metasomatism between 4.5-7 GPa is $\Delta \log f \mathrm{O}_{2}(\mathrm{FMQ})=-2.55$ to -1.43 , but the variation at a given pressure is $<0.37 \log$ units (Fig. $2 \mathrm{~b}$ ).

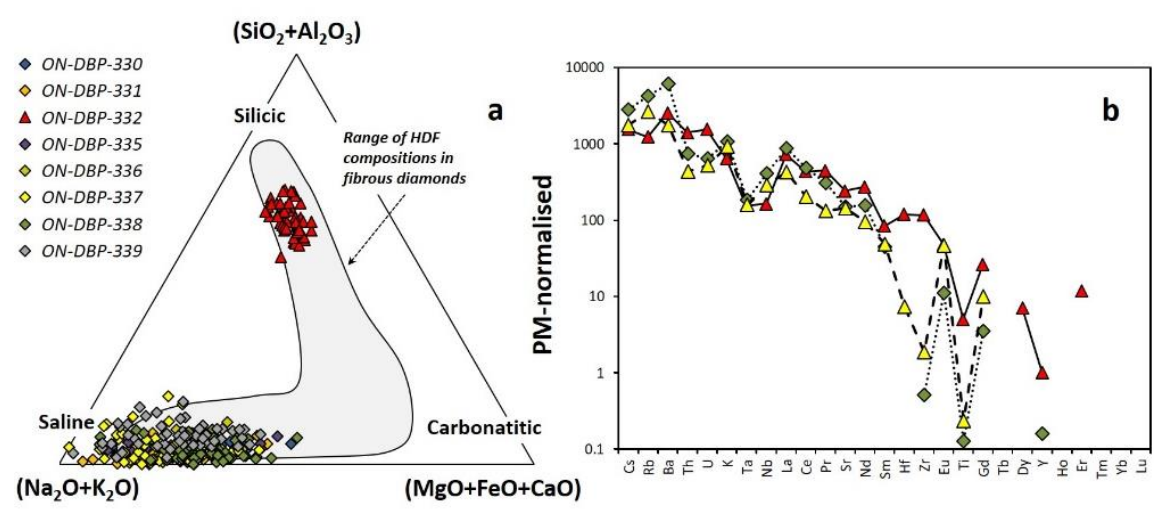

Figure 1: Compositions of HDF microinclusions in diamonds from DeBeers-Pool kimberlites. (a) Ternary diagram (in wt.\%) showing the HDF compositions in DeBeers-Pool diamonds compared to the global HDF dataset. (b) PM-normalized average trace element patterns of two saline and one silicic HDFbearing diamonds that carry no mineral microinclusions.

\section{Discussion}

The chemical compositions of HDF in diamonds reflect the various sources of deep mantle metasomatic fluids that impact the lithosphere and form diamonds. Weiss et al. (2015) reported strong and correlative positive anomalies of Eu and $\mathrm{Sr}$, as evidence for seawater-altered subducted slabs as the source of HDFs having saline compositions in a set of diamonds from the Slave Craton. Saline HDFs in the analyzed DeBeers-Pool diamonds are not characterized by pronounced positive anomalies of Eu and Sr; in most cases they show small positive or no anomalies for $\mathrm{Sr}$ and $\mathrm{Eu} / \mathrm{Sm}<1$. These features do not imply an explicit relationship to recycled oceanic crust. However, geothermobarometry of mineral microinclusions in the DeBeers-Pool diamonds reflect the interaction of low temperature saline HDFs with lithospheric rocks. In addition, the redox state of the saline HDFs is higher than the local SCLM and approaches that of the EMOD buffer (Fig. 2). These two lines of evidence indicate that the saline metasomatic agent that altered the southwestern Kaapvaaal SCLM was 'cold and oxidized', and could not originate from the ambient lithosphere nor from the underlying 'hotter' asthenosphere. We therefore suggest that the saline HDFs in DeBeers-Pool diamonds are linked to a subducting slab. Given the compositional similarities of these trapped HDFs, it is reasonable they all formed during a single metasomatic event and over a short period in time. Considering the low-aggregated state of nitrogen in these diamonds and the timing of the Karoo flood basalt volcanism, which likely involved elevated thermal conditions of the South African lithosphere, we suggest that the saline metasomatism occurred slightly before the kimberlite eruption at $\sim 85 \mathrm{Ma}$. The nitrogen aggregation state of the silicic HDF-bearing diamond restricts its formation to an earlier and different metasomatic event. The silicic nature of metasomatism may indicate a relationshop with silicic melts that intruded the southwestern Kaapvaal lithosphere during the Karoo magmatism, ca. 200 Myr. 
The P-T field as determined by geothermobarometry of mineral microinclusions in the saline HDF-bearing diamonds overlap with equilibration temperatures of touching inclusion-pairs in monocrystalline diamonds from the same sources, and are altogether lower, on average, by $150-250^{\circ} \mathrm{C}$ compared to the observed P-T gradient of xenoliths from both Group II and Group I kimberlites (Fig. 2a). A significant temperature difference persists, even when a possible underestimation of $\sim 60^{\circ} \mathrm{C}$ is accounted for in the diamond inclusions, due to differences between the Grt-Opx thermometer (used for the inclusions) and the twopyroxene thermometer (used for the xenoliths). If mantle-derived xenoliths from the southwestern Kaapvaal lithosphere record a snapshot of thermal advection during the last event of metasomatism and/or kimberlite eruption, then the P-T conditions of the xenoliths, the non-touching mineral microinclusions, and the touching inclusion pairs, should all plot along a similar P-T gradient. However, this is not the case. Moreover, we observe a gap between the $f \mathrm{O}_{2}$ conditions of peridotitic xenoliths and saline metasomatism (Fig. 2b). This implies that the redox state recorded by peridotitic xenoliths from the southwestern Kaapvaal lithosphere does not represent interaction with saline HDFs, but rather is a reflection of the pre-existing lithospheric $\mathrm{fO}_{2}$ conditions. To reconcile the temperature and oxygen fugacity discrepancy between xenoliths and inclusions in diamond, we suggest that xenoliths did not equilibrate during the last saline metasomatic event and/or kimberlite eruption. Thus the P-T- $f \mathrm{O}_{2}$ gradients they record represent preexisting lithospheric conditions, likely expressing the last major thermal event in the Kaapvaal craton (i.e the Karoo magmatism at $200 \mathrm{Myr}$ ). Local and small volume eruptions of Mesozoic kimberlites had limited thermal influence on the lithosphere, while the last metasomatic event by saline fluids led to local SCLM cooling and shifted the redox state of the impacted SCLM to more oxidized conditions upon fluid-rock interaction.

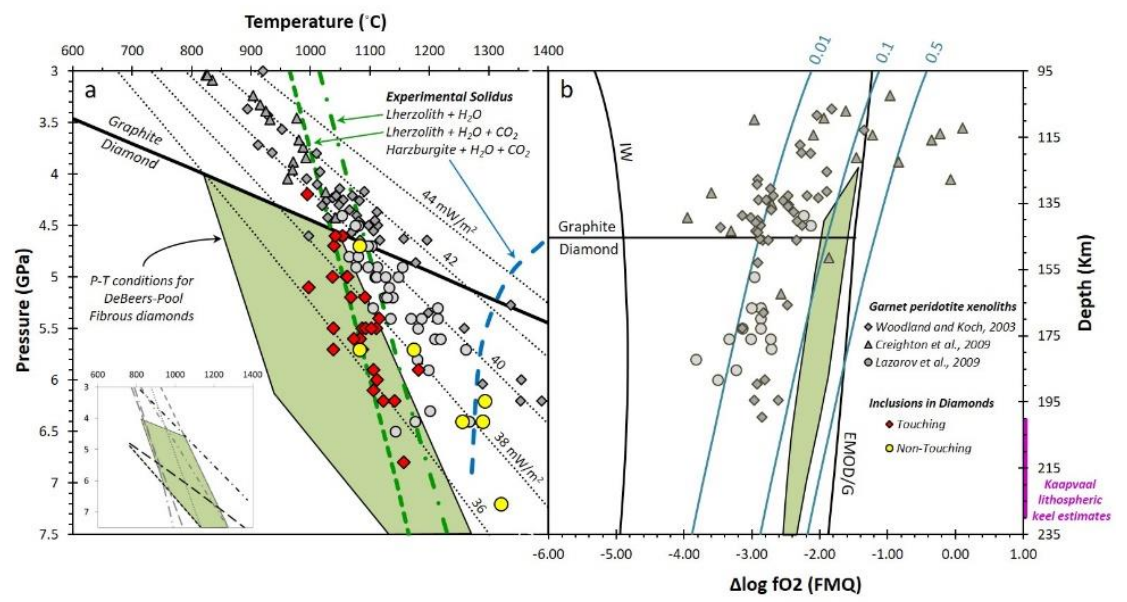

Figure 2: Temperature-pressure$\mathrm{fO}_{2}$ conditions of inclusions in diamond and xenoliths from the southwestern Kaapvaal Craton. (a) possible P-T conditions of saline metasomatism (green area); the inset shows the different Ol-GrtCpx-Opx thermometers and barometers used to define these conditions. Also shown are P-T conditions of mineral inclusions in DeBeers-Pool diamonds; 36-44 $\mathrm{mW} / \mathrm{m}^{2}$ continental geotherms; the graphite-diamond transition; the solidus for lherzolite $+\mathrm{H}_{2} \mathrm{O}+\mathrm{CO}_{2}$,

lherzolite $+\mathrm{H}_{2} \mathrm{O}$, and the solidus for harzburgite $+\mathrm{H}_{2} \mathrm{O}+\mathrm{CO}_{2}$. (b) $f \mathrm{O}_{2}$ variations of saline HDFs as a function of pressure (green area). Also shown are the iron-wüstite buffer reaction (IW); graphite-diamond transition reaction and enstatite+magnesite $=$ olivine+graphite/diamond reaction $\left(\right.$ EMOG/EMOD); the maximum- $f \mathrm{O}_{2}$ stability of carbonatebearing melts (blue lines with molar fraction of $\mathrm{CO}_{2}$ on top; Stagno and Frost, 2010).

\section{References}

Stagno V, Frost DJ (2010) Carbon speciation in the asthenosphere: Experimental measurements of the redox conditions at which carbonate-bearing melts coexist with graphite or diamond in peridotite assemblages. Earth and Planetary Science Letters 300:72-84.

Weiss Y, McNeill J, Pearson DG, Nowell GM, Ottley CJ (2015) Highly saline fluids from a subducting slab as the source for fluid-rich diamonds. Nature 524:339-342. 